\title{
Greenhouse gas mitigation and offset options for suckler cow farms: an economic comparison for the Swiss case
}

\author{
Simon Briner • Michael Hartmann • Robert Finger • \\ Bernard Lehmann
}

Received: 3 July 2011 / Accepted: 10 October 2011 /

Published online: 26 October 2011

(C) Springer Science+Business Media B.V. 2011

\begin{abstract}
We assessed the economic suitability of 4 greenhouse gas (GHG) mitigation options and one GHG offset option for an improvement of the GHG balance of a representative Swiss suckler cow farm housing 35 Livestock units and cultivating 25 ha grassland. GHG emissions per kilogram meat in the economic optimum differ between the production systems and range from 18 to $21.9 \mathrm{~kg} \mathrm{CO}$-eq./kg meat. Only GHG offset by agroforestry systems showed the potential to significantly reduce these emissions. Depending on the production system agroforestry systems could reduce net GHG emissions by $66 \%$ to $7.3 \mathrm{~kg} \mathrm{CO}$-eq. $/ \mathrm{kg}$ meat in the most intensive system and by $100 \%$ in the most extensive system. In this calculation a carbon sequestration rate of $8 \mathrm{t} \mathrm{CO}_{2} /$ ha/year was assumed. The potential of a combination of the addition of lipids to the diet, a cover of the slurry tank and the application of nitrification inhibitors only had the potential to reduce GHG emissions by $12 \%$ thereby marginal abatement costs are increasing much faster than for agroforestry systems. A reduction of the $\mathrm{GHG}$ emissions to $7.5 \mathrm{~kg} \mathrm{CO} \mathrm{CO}_{2}$-eq. $/ \mathrm{kg}$ meatpossible with agroforestry only_raised costs between $0.03 \mathrm{CHF} / \mathrm{kg}$ meat and $0.38 \mathrm{CHF} / \mathrm{kg}$ meat depending on the production system and the state of the system before the reduction. If GHG emissions were reduced maximally average costs ranged between $0.37 \mathrm{CHF} / \mathrm{kg}$ meat, if agroforestry had the potential to reduce net $\mathrm{GHG}$ emissions to $0 \mathrm{~kg} \mathrm{CO}_{2}$-eq., to 1.17 CHF/kg meat if also other options had to be applied.
\end{abstract}

S. Briner $(\bowtie) \cdot$ R. Finger $\cdot$ B. Lehmann

Agri-food \& Agri-environmental Economics Group, ETH Zürich, Sonneggstrasse 33, 8092 Zürich, Switzerland

e-mail: briners@ethz.ch

R. Finger

e-mail: rofinger@ethz.ch

B. Lehmann

e-mail: lehmann@ethz.ch

M. Hartmann

Research Institute of Organic Agriculture (FiBL), 5070 Frick, Switzerland

e-mail: michhartmann@gmail.com 
Keywords Abatement costs · Agroforestry - Greenhouse gas mitigation · Greenhouse gas offset $\cdot$ Meat $\cdot$ Simulation $\cdot$ Suckler farming $\cdot$ Whole-farm model

\section{Introduction}

The contribution of agriculture to climate-relevant emissions has emerged as a major concern for scientists, policy makers and the public. Methane $\left(\mathrm{CH}_{4}\right)$ and nitrous oxide $\left(\mathrm{N}_{2} \mathrm{O}\right)$ constitute crucial non- $\mathrm{CO}_{2}$ greenhouse gases (GHG). From a global perspective livestock is responsible for around $80 \%$ of agricultural and $18 \%$ of total GHG emissions (FAO 2006). Moreover $60 \%$ of nitrous oxide and about $50 \%$ of methane are associated with agricultural activities such as keeping livestock (here in particular from enteric fermentation) and soil cultivation (IPCC 2007). Pressure from policy and consumers to reduce these emissions are increasing worldwide. For example in Australia Government is discussing the implementation of a tax on GHG emissions (Nelson et al. 2011). Even if agriculture is not addressed within these schemes it offers farmers the possibility to trade emission certificates as a new source of income. On the other hand, large retailers in France label their products with a carbon footprint giving consumers the possibility to choose the most climate-friendly product (Cousin 2009).

Strategies to cope with the challenge of mitigating GHG emissions from agriculture can occur through (1) changes in plant and livestock production, (2) changes in the intensity of production activities, and (3) adoption of specific technologies (cf. UNFCCC 2008). While the last group comprises, e.g., slurry additives and coverage of slurry tanks, the first group involves enhanced grazing and agroforestry.

In Switzerland in particular suckler farming is of increasing importance. This development is caused by a rising consumer demand for meat produced by animalfriendly livestock husbandry. In order to reduce the environmental loads from suckler farming, strategies to mitigate climate relevant emissions have to be considered.

Both the high degree of heterogeneity in farming practices and the transboundary character of GHG emissions make it challenging to assess mitigation potentials. Therefore, assessment of mitigation strategies necessitates an analysis at a more disaggregated level (e. g. at the farm level) (Crosson et al. 2011). In addition, the implications of agricultural production imply links between GHG, the nitrogen cycle and other environmental factors. Thus, a holistic view of the agricultural production process is required in order to evaluate different mitigation strategies (Schils et al. 2005; Stewart et al. 2009).

Different studies assess and compare greenhouse gas emissions from different suckler cow farming systems using life cycle analysis approaches (e.g. Beauchemin et al. 2010; Casey and Holden 2006; Foley et al. 2011). However these models do not consider economic rationalities (i.e. farmers' responses) and thus cannot estimate the costs associated with a reduction of GHG emissions. Veysset et al. (2010) present a modeling framework that assesses both, economic performance as well as GHG balance of French suckler cow farms. They show that the production system has an impact as well on the farm GHG balance as on the economic performance. Meyer-Aurich (2005) calculates marginal GHG abatement costs for a cropping farm in Germany, showing that marginal abatement costs at the farm level can help to approach optimal abatement strategies. For the dairy sector different models already exist that have proven to be suitable tools to explicitly assess the economic performance of mitigation options (for a review on such models see Schils et al. 2005).

In this article, we investigate the opportunities of low GHG emitting suckler cow production systems in Switzerland. Moreover, we quantify the marginal and average 
abatement costs for different mitigation strategies in grassland-based suckler farms. In our analysis, we consider 4 mitigation strategies: (1) switching to alternative production systems, (2) lipid fodder supplements, (3) the coverage of slurry tanks, (4) adding nitrification inhibitors to slurry, and one offset strategy: the use of agroforestry for GHG offset.

To assess the options mentioned above, an integrated bio-economic model, which links the agricultural production process to environmental factors, is applied at a representative Swiss suckler cow farm. In this model, marginal abatement costs are calculated. In addition, we investigate the impact of the reduction of GHG emissions on the price of meat, which is relevant from the consumers' and farmers' perspective. Our study provides information for farmers and policy makers about the suitability of the assessed option. To reach this goal we aim to answer the following three research questions: 1) What is the potential of the different options to improve GHG-balance of the farm? 2) What is the (economically) optimal combination of the different mitigation options? 3) What are the supplemental costs (e.g. for consumers) for carbon improved meat?

The remainder of this paper is organised as follows: Section 2 presents the methodological framework of the employed bio-economic model and an overview of the here considered mitigation and offset strategies. Results and discussions are presented in Section 3, while Section 4 concludes our analysis.

\section{Data and methods}

Our Integrated Suckler Cow Optimisation model (INTSCOPT) was designed to evaluate different GHG mitigation options as well as the biophysical and economic potential of agroforestry. This model was constructed to allow quantification of all direct and indirect gaseous emissions from suckler cow farms to assess mitigation and offset options.

INTSCOPT is based on linear programming (LP), since this approach has proven to be a suitable method for considering both economic and environmental constraints, especially in the case of farming systems (Janssen and Van Ittersum 2007). The structure of INTSCOPT takes the form of a standard LP model, as described in Table 1. We apply our model to a single existing, exemplary farm. This farm is located in the Swiss highlands on an elevation of 800 m.a.s.l. It is characterized by a total farm area of 25 ha, and has a maximum housing capacity of 35 livestock units (LU), what is a representative size for Swiss suckler cow farms. Land use activities are grassland based, i.e. no crop production is considered because soil and climate conditions are not suitable. Thus all feed concentrates are assumed to be purchased on the market.

The goal function underlying this model is the maximization of total (i.e. farm-level) gross margins for the farmer. Gross margins are taken as goal function because our analysis focuses on a short time horizon, and farmers can thus not adjust overhead and fix costs, but focus on the adjustment of direct, assignable (i.e. variable) costs of their activities. The objective function is measured in monetary units $(Z)$ and is defined as follows:

$$
\operatorname{Max} Z=\sum \text { returns }-\sum \text { assignable cost }-\sum \text { mitigation costs }+\sum \text { subsidies, s.t. constraints }
$$

In the maximization process the model has the ability to optimize the number of animals as well as land-use, i.e. the choice of grasslands of different intensities and agroforestry. Since the diet is calculated endogenously also the choice of the amount of concentrate feed 


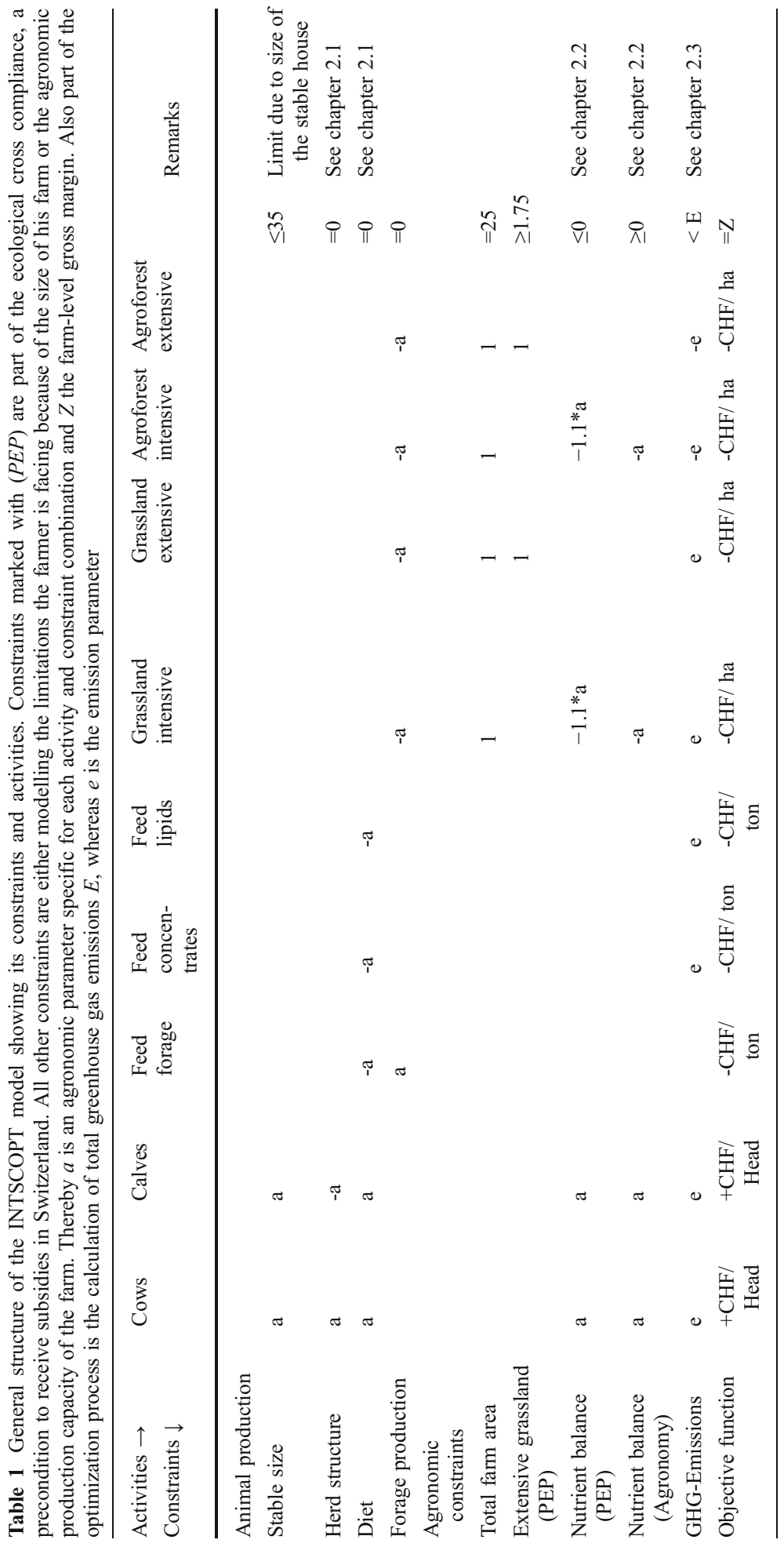


or lipids in the diet is part of the optimization process. Also part of the optimization process is the implementation of the assessed GHG-mitigation measures.

Equation 1 shows that farm-level gross margins are maximized subject to specific constraints. An overview over these constraints is given in Table 1. They address for instance, the farm size (i.e. the used area has to be equal to the total farm size), the production of forages (i.e. forages are produced on the farm), but also address cross compliance restrictions that have to be fulfilled to receive general direct payments. For grassland based suckler farms the most important cross compliance restrictions are that at least $7 \%$ of the total farm area has to be cultivated with extensive grassland, and the nutrient balance of the farm has to be balanced. ${ }^{1}$

To optimise both profit and GHG emissions, an iterative procedure described by de Wit et al. (1988) has been chosen. The procedure consists of a number of optimisations of the total gross margin, whereas the GHG emissions are lowered in every optimisation round by $2.5 \mathrm{t} \mathrm{CO}_{2}$-eq. ${ }^{2}$ while keeping the animal husbandry system and the amount of meat production constant. Afterwards, the model is applied to 1) calculate the total (i.e. farm-level) gross margins of different production systems, 2) assess the environmental and economic performance of different GHG mitigation and offset options in an integrated approach and 3) to estimate marginal and average abatement costs.

In the following sections, the crucial parts of the model, including the calculation of the emission factors, are described. At the end of this section, a summary table on key-variables and assumptions (i.e. on prices, costs, direct payments, grassland yields, etc.) used in the model is presented (Table 5).

\subsection{Animal production systems and farm structure}

Table 2 shows the characteristics of the three considered suckler cow production systems.

For the optimisation of the feed mix, the year is split into two periods: winter and summer. Whereas in winter, hay and silage of different qualities are available, during the summer, fodder from pastures also is part of the feed mix. In both periods, forage can be supplemented by concentrates and fat. Determining the composition of the feed mix is part of the optimisation process. The daily energy requirement for every animal is calculated according to its weight and its needs (production, growth) in every period. These constraints are complemented by upper and lower limits of daily dry matter intake calculated on the basis of the animal's weight. To guarantee the availability of crude protein in the feed mix, an upper and lower bound is defined, depending on the energy intake. The calculations of the feed requirements and the composition of the different feeds are based on data provided by Arrigo et al. (1994).

The model assumes that the animals are kept in free-stall housing in which the number of stalls is flexible according to the age of the animals. Animals older than 15 months are kept in cubicles, whereas younger cattle are kept on deep litter. It is assumed that a change between the housing systems does not require much effort. Therefore, the only building constraint in INTSCOPT is the total number of LU, which in this case is 35 (cf. Table 2).

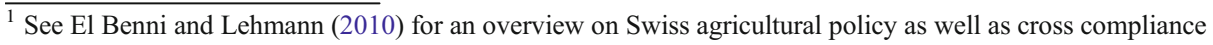
restrictions.

${ }^{2}$ To make the results comparable between the different production systems it was necessary to reduce GHGemissions by identical absolute values. Reduction steps of $2.5 \mathrm{t} \mathrm{CO}_{2}$-eq. were chosen as a compromise between high accuracy of the results and required time for computation.
} 
Table 2 Characteristic parameters of beef production in the three production systems presented in this study: Angus, Charolais and Galloway

\begin{tabular}{llll}
\hline Production parameter & \multicolumn{2}{l}{ Production system } & \\
\cline { 2 - 4 } & Angus & Charolais & Galloway \\
\hline Weight of the cow $[\mathrm{kg}]$ & 625 & 800 & 525 \\
Calves per year [1/year] & 1 & 1 & 1 \\
Weight of calf at birth $[\mathrm{kg}]$ & 36 & 45 & 27 \\
Age at slaughtering day [months] & 10 & 15 & 25 \\
Average growth per day [g/day] & 1100 & 1133 & 700 \\
Live weight at slaughter (LW) $[\mathrm{kg}]$ & 364 & 550 & 482 \\
Carcass weight $(\mathrm{CW})[\mathrm{kg}]$ & 205 & 310 & 270 \\
Milk production $[\mathrm{kg} / \mathrm{year}]$ & 2500 & 3000 & 2000 \\
Max. number of Livestock Units $[\mathrm{LU}]$ & 35 & 35 & 35 \\
Max. number of cows & 35 & 26 & 18 \\
\hline
\end{tabular}

\subsection{Nutrient balance and N-cycle}

The outcome of the model is restricted by two different nutrient balances. The first balance ensures that the modelled farm fulfils the cross compliance requirements (Proof of Ecological Performance (PEP), see El Benni and Lehmann (2010) for details), which represents a criteria that must be met to receive direct payments in Switzerland. In order to fulfil the PEP the amount of nutrients spread may not exceed $110 \%$ of the nutrient demand of crops and grassland. The calculation of this nutrient balance in the model was done according to the official calculation criteria (for details see Suisse-Bilanz, Amaudruz et al. 2003).

Because GHG and nitrogen emissions are linked, a second refined balance was calculated for nitrogen. This second nitrogen balance integrates the different compartments of the farm nitrogen cycle. The amount of artificial fertilizer that is purchased is calculated as the difference between the demand for nitrogen by the grassland to reach yields as high as specified for the different intensity levels and the nitrogen available in manure. The available nitrogen in manure is calculated as the amount of nitrogen in the feedstuff - including both, roughage and concentrate feedstuff - minus the amount of nitrogen lost by selling animals, gaseous emissions and emissions through leakage. The different parts of the cycle are calculated according to the methods presented in Table 3 .

\subsection{Calculation of GHG emissions}

In our model, we account for all GHG emissions on a farm, including indirect nitrous oxide emissions associated with $\mathrm{N}$ losses and selected pre-chain emissions from imported products. GHG emitted after the products, i.e. meat and timber, have left the farm are not considered. On-farm emissions are calculated applying the IPCC methodology (Houghton et al. 1997; IPCC 2000). Because emission levels are climate- and management-specific (Crosson et al. 2011), these methodologies have been adapted to Swiss conditions. The various on-farm emissions, their sources and the underlying methods are described in 
Table 3 Description of the different compartments of the nitrogen cycle as modelled in INTSCOPT as well as the underlying methods. The amount of nitrogen flowing through the different compartments is influenced by the here shown factors

\begin{tabular}{llll}
\hline $\begin{array}{l}\text { Compartement } \\
\text { of the N-cycle }\end{array}$ & $\begin{array}{l}\text { Source of } \\
\text { nitrogen }\end{array}$ & $\begin{array}{l}\text { Influencing factors for the different } \\
\text { N-flows considered in INTSCOPT }\end{array}$ & $\begin{array}{l}\text { References for the methods } \\
\text { to assess each compartment of } \\
\text { N-cycle }\end{array}$
\end{tabular}

\begin{tabular}{|c|c|c|c|}
\hline \multicolumn{4}{|l|}{ System inflow } \\
\hline \multicolumn{2}{|l|}{ Fertiliser } & \multicolumn{2}{|l|}{ Type of fertiliser/nutrient content } \\
\hline \multicolumn{2}{|l|}{ Concentrate } & Type of concentrate & Arrigo et al. 1994 \\
\hline \multicolumn{2}{|l|}{$\begin{array}{l}\text { Biological N } \\
\text { Fixation }\end{array}$} & Land-use intensity & Schmid et al. 2000 \\
\hline \multicolumn{4}{|l|}{ System outflow } \\
\hline Meat N-content & Animal & Amount of meat produced & Arrigo et al. 1994 \\
\hline \multirow[t]{2}{*}{$\mathrm{NH}_{3}$} & Manure & $\begin{array}{l}\text { Housing system, manure storage } \\
\text { and spread, pasture management, } \\
\text { manure storage }\end{array}$ & Reidy and Menzi 2005 \\
\hline & Land use & $\begin{array}{l}\text { Type of fertiliser or manure, manure } \\
\text { management }\end{array}$ & \\
\hline $\mathrm{NO}_{3}$ & Land use & & Houghton et al. 1997 \\
\hline \multirow[t]{2}{*}{$\mathrm{N}_{2} \mathrm{O}$} & Manure & $\begin{array}{l}\text { Housing system, type of manure, } \\
\text { manure storage }\end{array}$ & $\begin{array}{l}\text { Schmid et al. 2000; } \\
\text { Schmid et al. } 2001\end{array}$ \\
\hline & Land use & Crop residues, $\mathrm{NH}_{3}$ loss & \\
\hline $\mathrm{NO}_{\mathrm{x}}$ & $\begin{array}{l}\text { Manure and } \\
\text { fertiliser }\end{array}$ & $\begin{array}{l}\text { Amount of } \mathrm{N} \text { in manure } \\
\text { and fertiliser }\end{array}$ & Schmid et al. 2000 \\
\hline
\end{tabular}

Table 4. To compare the different emissions with each other, methane and nitrous oxide are converted into $\mathrm{CO}_{2}$ equivalents following IPCC (2007).

Pre-chain emissions are emissions associated with the buying, i.e. importation into the farm system, of production factors such as concentrate feedstuff and artificial fertiliser. Note that pre-chain emissions for the consumption of electricity on the farm as well as for the construction of buildings and machinery are not considered since this study focuses only on short term optimization hence changes in buildings and machinery are not part of the optimization process. Vergé et al. (2007) show for the Canadian dairy sector that the neglected indirect GHG emissions account only for 5.1\% of total GHG emissions. Since use of electricity in the here considered beef production is lower than in dairy production, we assume that our framework covers at least $95 \%$ of total GHG-emissions.

\subsection{Selected mitigation and offset strategies for agricultural GHG emissions}

Compilations of mitigation and offset strategies for agriculture are provided by, e.g. Martin et al. (2010), Wright and Klieve (2011), and UNFCCC (2008). With a focus on grasslandbased suckler farming, this section addresses the mitigation practices and their relative reduction potentials, which are included in this assessment: They have been chosen since they do not require large investments as for example anaerobic digestion, or separation of slurry do. In addition their impact has been proven outside a laboratory environment (Veysset et al. 2010; Martin et al. 2010; Amon et al. 2006; Weiske et al. 2001) and these mitigation options are feasible for use in practice as also are agroforestry systems (Eichhorn et al. 2006). 
Table 4 Factors influencing greenhouse gas emissions as considered in INTSCOPT as well as references for the underlying greenhouse gas calculation methods

\begin{tabular}{|c|c|c|c|}
\hline $\begin{array}{l}\text { Greenhouse } \\
\text { Gas }\end{array}$ & Source of greenhouse gas & $\begin{array}{l}\text { Factors influencing the } \\
\text { emission of the different } \\
\text { greenhouse gases }\end{array}$ & $\begin{array}{l}\text { References for methods } \\
\text { applied to model the emission } \\
\text { of each greenhouse gas }\end{array}$ \\
\hline \multirow[t]{2}{*}{$\mathrm{CH}_{4}$} & Enteric fermentation & $\begin{array}{l}\text { Animal-specific methane } \\
\text { rate, feed mix, lipid } \\
\text { supplementation }\end{array}$ & $\begin{array}{l}\text { Houghton et al. 1997; } \\
\text { Minonzio et al. } 1998\end{array}$ \\
\hline & Manure & $\begin{array}{l}\text { Amount of different } \\
\text { manures, feed mix, } \\
\text { housing system, pasture } \\
\text { management }\end{array}$ & \\
\hline \multirow[t]{3}{*}{$\mathrm{N}_{2} \mathrm{O}$} & Manure & $\begin{array}{l}\text { Amount of different types } \\
\text { of manure, manure } \\
\text { management }\end{array}$ & Houghton et al. 1997 \\
\hline & Land-use & $\begin{array}{l}\text { Fertiliser, N-fixation, har- } \\
\text { vest residues, }\end{array}$ & Schmid et al. 2000, 2001 \\
\hline & Indirect & $\begin{array}{l}\text { Loss of } \mathrm{N} \text { in different } \\
\text { compounds }\end{array}$ & $\begin{array}{l}\text { Schmid et al. 2000, see } \\
\text { Table } 4\end{array}$ \\
\hline $\mathrm{CO}_{2}$ & Tractor/Machinery & Land-use intensity & $\begin{array}{l}\text { Houghton et al. 1997; } \\
\text { Gazzarin and Albisser } \\
\text { Vögeli } 2010\end{array}$ \\
\hline \multirow[t]{2}{*}{$\begin{array}{l}\text { Pre-chain } \\
\text { emissions }\end{array}$} & $\begin{array}{l}\text { Production and transport } \\
\text { of concentrate feedstuff }\end{array}$ & $\begin{array}{l}\text { Composition of the animal's } \\
\text { diet }\end{array}$ & $\begin{array}{l}\text { Van der Werf et al. 2005; } \\
\text { Bernesson 2004; Williams } \\
\text { et al. } 2006\end{array}$ \\
\hline & $\begin{array}{l}\text { Production and transport } \\
\text { of artificial fertiliser }\end{array}$ & $\begin{array}{l}\text { Land-use intensity, } \\
\text { available on-farm manure }\end{array}$ & Williams et al. 2006 \\
\hline
\end{tabular}

\subsubsection{Different animal production systems}

The animal production system has a major effect on the emission of GHG. Veysset et al. (2010) assessed differences of up to $10 \%$ in emitted GHG among grazing suckler farming, depending on the production system. We consider three common Swiss production systems in our analysis named after breeds that are suitable for the respective systems: Angus, Charolais and Galloway. The productivity per LU for Angus and Charolais is quite high because after 10 and 15 months (Boessinger et al. 2009; Mutterkuh 2011), respectively, the optimal live weight for slaughter must be attained. While the Angus and Charolais systems need to be managed rather intensively, the Galloway system can be applied on marginal sites using low-nutrient feed mixes (Mutterkuh 2011). For a detailed description of the different systems see Table 2 .

\subsubsection{Lipid supplements}

Whereas different strategies, e.g. defaunating agents, or ionophores, did not yet provide convincing results in the decrease of methane production in ruminant's digestion, supplementation of lipids to the diet leads to a significant decrease of methane emissions (Wright and Klieve 2011) without decrease in performance (Grainger and Beauchemin 2011). Lipids reduce methane emissions through decreased organic matter fermentation, activity of methanogens and protozoal, and hydrogenation of fatty acids for lipids rich in unsaturated fatty acids (Johnson and Johnson 1995). However, the measured efficiency 
Table 5 Summary of economic model parameters including prices for farm products, production factors, machinery, and mitigation options based on prices in the year 2009. In the lower part a description of the yields and carbon sequestration rates of the different land-use activities is given. Data mainly origins from publication for extension services in Switzerland

\begin{tabular}{|c|c|c|c|}
\hline Parameter in INTSCOPT & Amount & Unit & Reference for data \\
\hline \multicolumn{4}{|l|}{ Returns } \\
\hline Meat Calve & 10.3 & $\mathrm{CHF} / \mathrm{kg} \mathrm{CW}$ & \multirow[t]{2}{*}{ Boessinger et al. 2009} \\
\hline Meat Cow & 7.9 & $\mathrm{CHF} / \mathrm{kg} \mathrm{CW}$ & \\
\hline \multicolumn{4}{|l|}{ Subsidies } \\
\hline Grassland intensive & 1040 & $\mathrm{CHF} / \mathrm{ha}$ & \multirow[t]{4}{*}{ Swiss Federal Council 1998} \\
\hline Grassland mid-intensive & 1040 & $\mathrm{CHF} / \mathrm{ha}$ & \\
\hline Grassland extensive & 1740 & $\mathrm{CHF} / \mathrm{ha}$ & \\
\hline Cows & 1130 & $\mathrm{CHF} / \mathrm{LU}$ & \\
\hline \multicolumn{4}{|l|}{ Costs } \\
\hline Young cow & 450 & $\mathrm{CHF} /$ cow/year & \multirow[t]{3}{*}{ Boessinger et al. 2009} \\
\hline General costs husbandry & 180 & $\mathrm{CHF} /$ cow & \\
\hline Concentrate feedstuff & 700 & $\mathrm{CHF} / \mathrm{t}$ & \\
\hline Fertilizer Urea & 636 & $\mathrm{CHF} / \mathrm{t}$ & \multirow[t]{4}{*}{ Schoch 2009} \\
\hline Fertilizer Ammonium Nitrate & 385 & $\mathrm{CHF} / \mathrm{t}$ & \\
\hline Fertilizer Triple Super Phosphate & 680 & $\mathrm{CHF} / \mathrm{t}$ & \\
\hline FertilizerPotash & 640 & $\mathrm{CHF} / \mathrm{t}$ & \\
\hline \multicolumn{4}{|l|}{ Machinery } \\
\hline Hay conservation & 106 & $\mathrm{CHF} / \mathrm{ha} / \mathrm{Cut}$ & \multirow[t]{4}{*}{ Gazzarin and Albisser Vögeli 2010} \\
\hline Silage conservation & 497 & $\mathrm{CHF} / \mathrm{ha} / \mathrm{Cut}$ & \\
\hline Slurry spreading & 2 & $\mathrm{CHF} / \mathrm{m}^{3}$ & \\
\hline Manure spreading & 18.6 & $\mathrm{CHF} / \mathrm{t}$ & \\
\hline \multicolumn{4}{|l|}{ Mitigation measure } \\
\hline Lipids & 266 & $\mathrm{CHF} / \mathrm{t}$ & $\begin{array}{l}\text { Price for sunflower oil } \\
\text { (SwissOlio 2007) }\end{array}$ \\
\hline Nitrification inhibitor & 0.65 & $\mathrm{CHF} / \mathrm{kg} \mathrm{N}$ & Landi Jungfrau 2008 \\
\hline Slurry tank cover & 2.06 & $\mathrm{CHF} / \mathrm{m}^{3}$ slurry & Peter 2008 \\
\hline Agroforestry & 0 & $\mathrm{CHF} / \mathrm{ha}$ & $\begin{array}{l}\text { Discounted value of wood is as } \\
\text { high as investments into plantation }\end{array}$ \\
\hline \multicolumn{4}{|l|}{ Yields } \\
\hline Grassland intensive & 12.2 & $\mathrm{t} / \mathrm{ha}$ & \multirow[t]{3}{*}{ Dütschler-Herrmann et al. 2006} \\
\hline Grasslandmid-intensive & 8.54 & $\mathrm{t} / \mathrm{ha}$ & \\
\hline Grassland extensive & 2.44 & $\mathrm{t} / \mathrm{ha}$ & \\
\hline Grassland intensive Agroforestry & 7.32 & $\mathrm{t} / \mathrm{ha}$ & \multirow{3}{*}{$\begin{array}{l}\text { Dütschler-Herrmann et al. 2006; } \\
\text { Kern } 2006\end{array}$} \\
\hline Grasslandmid-intensive Agroforestry & 5.124 & t/ha & \\
\hline Grassland extensive Agroforestry & 1.464 & t/ha & \\
\hline Age of trees at harvest & 20 & years & Palma et al. 2007 \\
\hline Carbon sequetsration Agroforestry & 8 & $\mathrm{t} \mathrm{CO}_{2} / \mathrm{ha}$ & Palma et al. 2007 \\
\hline
\end{tabular}

varies broadly, as Beauchemin et al. (2010) showed in a recent review. On average, a 1\% increase of lipids in the feed mix leads to an emission reduction of 5.6\%. Martin et al. (2010) indicated an average emission reduction of $4.8 \%$ per $1 \%$ increase of lipids in the dry matter. In the context of lipid supplements, however, it is important that the level of lipids 
must not exceed $6 \%$ of total dry matter content or else a depression of fodder intake may occur. Based on these two review studies, our analysis assumes a 5\% reduction in emissions per $1 \%$ lipid supplementation and a maximum of $6 \%$ lipids of total dry matter in the diet.

\subsubsection{Slurry tank coverage}

Covering slurry tanks can reduce methane, nitrous oxide and ammonia emissions. However, depending on the type of slurry coverage and the temperature, the rate of reduction varies. Covering slurry with a wooden lid leads to a reduction in methane emissions of $14 \%$ (winter) and $17 \%$ (summer), and a reduction in ammonia emissions of $28 \%$ (winter) and $54 \%$ (summer) (Amon et al. 2006). Based on this study, we assume in our model 15\%, $35 \%$, and $50 \%$ reductions in methane, nitrous oxide, and ammonia emissions, respectively, if slurry tanks are covered.

\subsubsection{Nitrification inhibitors}

Mineralisation of soil organic matter results in the release of ammonium $\left(\mathrm{NH}_{4}^{+}\right)$or ammonia $\left(\mathrm{NH}_{3}\right)$ (Firestone and Davidson 1989). In the process of nitrification, ammonium is oxidised via nitrite $\left(\mathrm{NO}_{2}{ }^{-}\right)$to nitrate $\left(\mathrm{NO}_{3}{ }^{-}\right)$. Nitrate easily can be leached into the groundwater, causing eutrophication, and both nitrite and nitrate can be denitrified to nitrous oxide (McNeill and Unkovich 2007). The application of nitrification inhibitors (NI) (e.g. 3,4-dimethylpyrazole phosphate (DMPP)) lowers the nitrification rate by reducing the activity of Nitrosomonas bacteria (Zerulla et al. 2001). Weiske et al. (2001) showed a 49\% reduction of nitrous oxide emissions when they applied DMPP on fertilised sites. A similar result of $48 \%$ (spring) and $61 \%$ (autumn) reduction in nitrous oxide emissions was demonstrated by Merino et al. (2005), who applied $1 \mathrm{~kg}$ of DMPP per hectare on slurry. Based on these and other studies, we assume a reduction potential of $50 \%$ for direct nitrous oxide emissions from pastures through the application of nitrification inhibitors.

\subsubsection{The agroforestry system}

Agroforestry systems contain a combination of a woody permanent crop with a crop or with grassland on the same area. Such systems result in diversified agricultural production, increased soil fertility, reduced nitrogen losses, improved landscape scenery, and enhanced biodiversity (Jose 2009; SAFE 2005). Compared to monocropping, one advantage of agroforestry is the ability to sequester carbon through storage in the permanent crop's wood or through the enrichment of organic matter in the soils (Palma et al. 2007). However, similar to other land use systems, the potential for carbon sequestration under agroforestry depends on multiple factors, e.g., the carbon content in existing biomass, the turnover of trees and the environmental conditions (Jose 2009). Thus, even at the small scale, the level of carbon sequestration varies. Palma et al. (2007) revealed a sequestration potential of $2.1 \mathrm{tC} / \mathrm{ha} / \mathrm{y}$ to $3 \mathrm{tC} / \mathrm{ha} / \mathrm{y}$ (equals $6.4 \mathrm{t} \mathrm{CO}_{2} / \mathrm{ha} / \mathrm{y}$ to $9.6 \mathrm{t} \mathrm{CO}_{2} / \mathrm{ha} / \mathrm{y}$ ) for agroforestry systems based on fastgrowing hybrid poplars. Based on these results, a sequestration potential of $2.5 \mathrm{tC} / \mathrm{ha} / \mathrm{y}$ (equals $8 \mathrm{t} \mathrm{CO}_{2} / \mathrm{ha} / \mathrm{y}$ ) is assumed in our analysis (Table 5). This can be seen as a rather conservative value. Arevalo et al. (2011) found 10 year old (monoculture) poplar plantations in Canada to sequester $8 \mathrm{tC} /$ ha in average per year considering also carbon sequestration in the soil. In order to analyze the senstivity of our results to the assumption on sequestration potentials, we additionally considered the lower and upper tails of sequestration potentials (i.e. $6.4 \mathrm{t} \mathrm{CO}_{2} / \mathrm{ha} / \mathrm{y}$ and $9.6 \mathrm{t} \mathrm{CO}_{2} / \mathrm{ha} / \mathrm{y}$ ) reported by Palma et al. (2007). 


\subsection{Land-use}

All land-use activities in our model are grassland-based. These activities differ only in the intensity of the pasture and the presence or absence of trees (i.e. agroforestry). According to Boessinger et al. (2010), three different grassland intensities are considered in INTSCOPT: intensive, mid-intensive, and extensive (Table 5). For any grassland type, the model can establish an agroforestry system. Because of the increasing competition for sunlight and other resources, the yield of grassland under trees is reduced by $40 \%$ (Kern 2006).

\section{Results}

In our simulation highest total gross margin was achieved with the production system based on the Charolais or Angus breed (Table 6). Because of the low amount of meat produced per year in the Galloway system, its total gross margin was $14 \%$ lower than in the other systems.

Depending on the production system, GHG emissions per kilogram of meat ranged between $18 \mathrm{~kg} \mathrm{CO}$-eq. $/ \mathrm{kg} \mathrm{CW}$ (Carcass Weight) for the Charolais system and $21.9 \mathrm{~kg}$ $\mathrm{CO}_{2}$-eq./kg CW for the Galloway system. These values were comparable to those reported by other studies, such as Casey and Holden (2006) and Foley et al. (2011), which reported emissions of $20 \mathrm{~kg} \mathrm{CO}$-eq. $/ \mathrm{kg} \mathrm{CW}$ and $15.7 \mathrm{~kg} \mathrm{CO}$-eq. $/ \mathrm{kg} \mathrm{CW}$ to $23.1 \mathrm{~kg} \mathrm{CO}_{2}$-eq. $/ \mathrm{kg}$ $\mathrm{CW}$, respectively for Irish beef production. However, the values reported in INTSCOPT were lower than emissions shown by Veysset et al. (2010) for Charolais based suckler cow systems in France (26.6-30.5 kg CO 2 -eq./kg CW).

\subsection{Mitigation options within the different production systems}

Results for the Charolais and Galloway systems are indicated in Fig. 1. Both covering the slurry tank and adding lipids to the feed mix had a rather low impact and fast increasing

Table 6 Model output for the different production systems in the initial state, when they are in the economic optimum: Greenhouse gas emissions in total $\left(G H G_{t o t}\right)$, per kilogram of meat produced $\left(G H G_{\text {prod }}\right)$, relative sources of the different greenhouse gases as well as total meat production and gross margins

\begin{tabular}{lllll}
\hline Description of Output parameter & Unit & \multicolumn{2}{l}{ Production system } \\
\cline { 4 - 5 } & & Angus & Charolais & Galloway \\
\hline GHG balance & & & & \\
$\mathrm{GHG}_{\text {tot }}$ & $\mathrm{t} \mathrm{CO}$-eq. & 175 & 176 & 134 \\
$\mathrm{GHG}_{\text {prod }}$ & $\mathrm{kg} \mathrm{CO}$-eq./kg CW & 19.4 & 18 & 21.9 \\
$\mathrm{GHG}$ sources & $\%$ & & & \\
$\mathrm{CH}_{4}$ digestion & $\%$ & 53 & 53 & 55 \\
$\mathrm{CH}_{4}$ manure & $\%$ & 5 & 5 & 6 \\
$\mathrm{~N}_{2} \mathrm{O}$ & $\%$ & 37 & 35 & 36 \\
$\mathrm{CO}_{2}$ machinery & $\%$ & 1 & 1 & 2 \\
$\mathrm{CO}_{2}$ inputs & & 4 & 6 & 2 \\
$\mathrm{Agricultural} \mathrm{Production}^{\text {Meat production }}$ & $\mathrm{kg} \mathrm{CW}$ & 9050 & 9800 & 6113 \\
Gross margin & $\mathrm{kCHF}$ & 138 & 138 & 119 \\
\hline
\end{tabular}


marginal abatement costs. The addition of fat to the cow's feed increased its net energy concentration, which might cause fattening problems. Due to the combination of this limitation and the cow's large contribution to total methane emissions, the impact of lipids was limited to a maximum reduction potential of $2 \%$ and $3 \%$ in the Galloway and the Charolais systems, respectively. Charolais cows required a higher energy concentration in the feed; thus a higher amount of lipids in the diet was tolerable and therefore the addition of fat had a higher potential for GHG reduction in the Charolais system than in the Galloway system. These results were consistent with a study by del Prado et al. (2010), which reported for dairy cows, which need fodder with higher energy concentration than suckler cows, a reduction potential of about $10 \%$ per kilogram of milk when lipids were added to the feed.

The curve progression for the marginal abatement costs of covering the slurry tank looked very similar to that of adding lipids to the diet (Fig. 1). The potential was limited to a decrease of $2 \%$ and $4 \%$ in the case of the Galloway and the Charolais systems. High abatement cost of the cover resulted from the small contribution of the slurry tank to total GHG emissions and the high cost for the construction of the cover .

Nitrous oxide emissions constituted about $50 \%$ of total emissions and our analysis indicated that nitrification inhibitors (NI) could reduce these emissions significantly. In comparison to the mitigation methods of adding lipids and covering the slurry tank, the marginal costs of applying NIs were relatively low (Fig. 1). The NI method of mitigation produced associated costs that were favourable in comparison to the lipid and cover options also because it reduced the need for expensive artificial nitrogen fertiliser.

With the application of a combination of all mitigation options, GHG emissions could be reduced by $12 \%$. These results were similar to those of other studies. For example, Hartmann et al. (2009) reported a mitigation potential of $5 \%$ and $2 \%$ with the addition of lipids and the slurry tank cover, respectively.

The above presented analyses focussed on technical mitigation options. In a subsequent step, the option to offset GHG emissions with on-farm agroforestry was taken into account. In the Galloway system, the establishment of an agroforestry system could reduce net GHG emissions to zero. In the case of the Charolais and the Angus systems, carbon sequestration in an agroforestry system had the potential to reduce emissions by $66 \%$ and $60 \%$, respectively. In combination with other mitigation options in these systems, respective
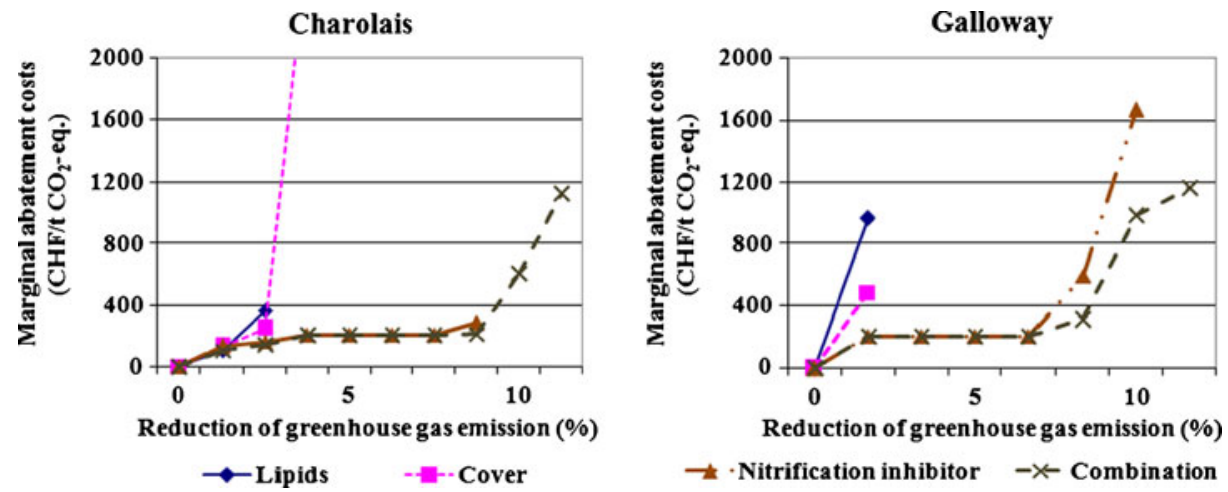

Fig. 1 Marginal abatement costs of different mitigation options for the Charolais (similar to Angus) and the Galloway systems. Marginal abatement costs are shown for the supplementation of lipids to the fodder (Lipids), for a cover on the slurry tank (Cover), for the application of nitrification inhibitor in manure management (Nitrification inhibitor) and for a combination of these three options (Combination) 
reductions of $77 \%$ and $70 \%$ could be reached. Agroforestry had a greater potential for the Galloway system because in the initial state land was managed low-intensively in this system. Hence, land was available to compensate for the smaller forage production caused by the enlarged agroforestry area. In the other systems, land use in the initial state of the system was relatively intensive, thus, the potential to intensify land use was lower. Compared to the other mitigation options, agroforestry was relatively inexpensive (in terms of costs per mitigated/sequestered ton of $\mathrm{CO}_{2}$-eq.). In all systems, a $50 \%$ reduction of $\mathrm{GHG}$ emissions was possible at marginal abatement costs of less than $57 \mathrm{CHF} / \mathrm{t} \mathrm{CO}_{2}$-eq.

In all systems average reduction costs per kilogram of meat were lower for the on-farm offset than for the other mitigation options considered (Table 7). Agroforestry was least expensive in the Galloway system since enough land was available for intensive use to compensate loss in fodder production due to expanded agroforestry.

With the application of all mitigation options (including agroforestry) within the production system, GHG emissions could be reduced to $5 \mathrm{~kg} \mathrm{CO}_{2}$-eq./kg $\mathrm{CW}$ or lower. Because agroforestry had the lowest marginal abatement costs compared to the other options, it was applied predominantly, while the other options were applied secondarily. In the Galloway system agroforestry potentially could reduce emissions to zero. A reduction of the emissions to $5 \mathrm{~kg} \mathrm{CO}$-eq. $/ \mathrm{kg} \mathrm{CW}$ in this system cost only $0.11 \mathrm{CHF} / \mathrm{kg} \mathrm{CW}$. In contrast, in the Angus and the Charolais system, agroforestry alone could reduce emissions only to a level of $7.76 \mathrm{~kg} \mathrm{CO}_{2}$-eq./kg CW and $6.12 \mathrm{~kg} \mathrm{CO}_{2}$-eq./kg CW, respectively. For this reduction a significant share of the farm area has to be covered by agroforests (Table 8). Reductions cost $0.37 \mathrm{CHF} / \mathrm{kg} \mathrm{CW}$ for the Angus system and $0.32 \mathrm{CHF} / \mathrm{kg} \mathrm{CW}$ for the Charolais system. To reduce emissions further to $5 \mathrm{~kg} \mathrm{CO}_{2}$-eq. $/ \mathrm{kg} \mathrm{CW}$, other options to mitigate GHG must be applied, e.g., supplementing lipids in the diet and utilising NIs. These additional mitigation strategies significantly increased reduction costs to $0.5 \mathrm{CHF} / \mathrm{kg}$ $\mathrm{CW}$ and $1.14 \mathrm{CHF} / \mathrm{kg} \mathrm{CW}$ for the Charolais and Angus systems, respectively.

Reduction costs depend on economic and ecological considerations. Average reduction cost per kilogram meat as well as the potential of the agroforest to offset GHG emissions were highly dependent on the assumed rate of carbon sequestration as indicated by a sensitivity analysis (Fig. 2). So in the case of the Angus system costs for the offset of $50 \%$

Table 7 Average additional costs per kilogram of meat (CHF/kg carcass weight) for the reduction of greenhouse gas emissions per kilogram meat for the different production systems applying either a combination of mitigation options (Mitigation w/o agroforestry) or a combination of mitigation and offset options (Mitigation and agroforestry). The values underlined in a grey colour specify the emissions level of the different systems in the economic optimum, i.e. the emission level that is reachable without extra costs. Every cell beyond the grey shaded means a reduction in greenhouse gas emissions applying one of the different options. n.a. means not available, i.e. there is no convergence to a solution for these emission levels

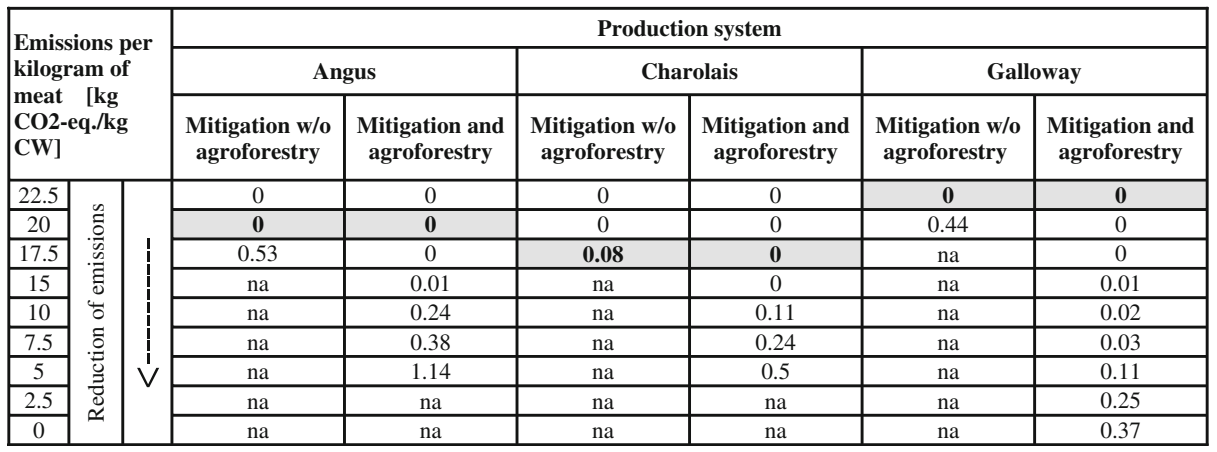


Table 8 Land-use in the different production systems if the systems are in their economic optimum (Initially) and if the systems are optimised with respect to their greenhouse gas emissions (GHG-offset)

\begin{tabular}{|c|c|c|c|c|c|c|c|}
\hline \multirow{2}{*}{$\begin{array}{l}\text { Main land-use } \\
\text { activity }\end{array}$} & \multirow{2}{*}{$\begin{array}{l}\text { Sub-land-use } \\
\text { activity }\end{array}$} & \multicolumn{2}{|l|}{ Angus } & \multicolumn{2}{|c|}{ Charolais } & \multicolumn{2}{|c|}{ Galloway } \\
\hline & & Initially & GHG offset & Initially & GHG offset & Initially & GHG offset \\
\hline \multirow[t]{2}{*}{ Intensive grassland } & Monoculture & 15.09 & 15.41 & 21.6 & 14.2 & 15.12 & 9.12 \\
\hline & Agroforestry & 0 & 7.84 & 0 & 9.05 & 0 & 11.71 \\
\hline \multirow{2}{*}{$\begin{array}{l}\text { Mid-intensive } \\
\text { grassland }\end{array}$} & Monoculture & 8.16 & 0 & 0 & 0 & 0.85 & 0 \\
\hline & Agroforestry & 0 & 0 & 0 & 0 & 0 & 0 \\
\hline \multirow[t]{2}{*}{ Extensive grassland } & Monoculture & 1.75 & 0 & 3.4 & 0 & 9.03 & 0 \\
\hline & Agroforestry & 0 & 1.75 & 0 & 1.75 & 0 & 4.17 \\
\hline
\end{tabular}

of GHG emissions were $21 \%$ higher if sequestration rate was at the lower than at the upper level as stated by Palma et al. (2007). It is therefore necessary that they are calculated independently for every country and farming system.

\section{Discussion}

We used an integrated bio-economic model to analyze the economic and environmental performance of 3 different suckler cow production systems in Swiss agriculture, with a particular focus on the mitigation of GHG emissions considering four mitigation and one offset strategies. Results confirm other studies (e.g. Casey and Holden 2006 and Crosson et al. 2011), which found, that the production system has a large impact on the emission level in the economic optimum. Mitigation options assessed in this study showed a limited possibility to mitigate GHG since they provoke fast increasing marginal abatement costs. The most efficient way to reduce GHG emissions is a combination of mitigation and offset options since marginal abatement costs are always lower than if mitigation options were implemented only. Above all, this combination showed a potential for the production system with the highest emissions per kilogram of

Fig. 2 Impact of the rate of carbon sequestration of the agroforestry systems on the average reduction costs per kilogram of meat. Sensitivity analysis was conducted at the example of the Angus production system. Maximum amount of greenhouse gas offset is $61 \%, 69 \%$ and $79 \%$ for sequestration rates of $6.4 \mathrm{t} \mathrm{CO}_{2} /$ ha/y (lower level stated by Palma et al. 2007), $8 \mathrm{t} \mathrm{CO}_{2} / \mathrm{ha} / \mathrm{y}$ (default level in this study) and $9.6 \mathrm{t} \mathrm{CO}_{2} /$ ha/y (upper level stated by Palma et al. (2007), respectively

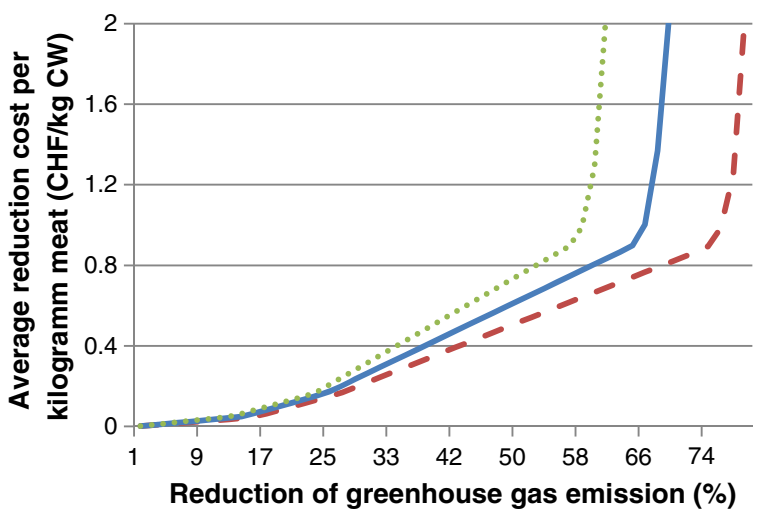

$$
- \text { - 9.6t CO2/ha } \quad \text { 8t CO2/ha } \cdots \cdots 6.7 \mathrm{t} \mathrm{CO} 2 / \mathrm{ha}
$$


meat in the economic optimum - the Galloway system-since in this system average additional costs are lowest and also a reduction of net greenhouse gas emissions to zero is possible. However the large agroforestry area needed might hinder farmers to maximize GHG offset and might limit its implementation on an area that can offset only a smaller share of GHG-emissions.

In our opinion agroforestry is especially suitable for extensive production systems not only in Switzerland but all around the world. The costs raised by the agroforestry systems are mainly opportunity costs of decreasing production and a loss in subsidies, i.e. parameters that depend on the local conditions. Farmers that receive lower prices for their products therefore will also face lower monetary losses by the implementation of agroforestry systems. It could therefore also be an opportunity for large scale beef farms, for instance in Australia, that could trade emission certificates when improving their carbon balance.

The use of LP as method for the simulation of decision making provides some caveats. LP is based on the neoclassical economic theory. In this theory, economic agents are profit optimizers. Combined with limited resources, represented by model restrictions, these normative model approaches incorporate the fundamental economic problem: making the best out of limited resources (Buysse et al. 2007). Of course, decision making is, other than the goal function of an LP, multidimensional considering different types of utilities (Edward-Jones 2006), e.g. farmers might be conservative regarding the use of specific methods if they strongly deviate from current practices (Karrer and Tikir 2010). Considering only monetary profit as a utility will neglect additional constraints farmers are facing. Therefore results of such a simulation must be considered as a type of best case solution. In order to overcome these drawbacks, linear programming methods can be augmented, for instance, by considering farmers' income risks (e.g. Finger et al. 2010) and integrating decision rules based on survey data (Möhring et al. 2010).

The accuracy of model results can be wrong if the model is based on an unsuitable design or false data. The results of such models therefore should be validated properly (Zander et al. 2008). For this purpose we compared some of the intermediate results with real farm data. For the amount of GHG emission as well as the efficiency of the assessed mitigation options this was not possible due to a lack of real data. The calculation of the emission is based on a widely accepted methodology (e.g. Vergé et al. 2007). The input parameters needed for calculation of emissions however inherent large uncertainty (Rypdal and Winiwarter 2001; Schmid et al. 2000). Parts of this uncertainty we tried to address by a comparison of our results with them of other studies as well as with a sensitivity analysis (Fig. 2). In further research this uncertainty should be assessed more in depth as for example done by Foley et al. (2011).

We are also aware that carbon fluxes in grasslands vary due to climatic and management conditions (Zeeman et al. 2010). Due to the long time period of 20 years considered in our empirical analysis and the assumption of constant grassland management, we assume that this variability is only of minor relevance for our analysis. Additionally a study of FordRobertson et al. (1999) suggests that a conversion of pastures to agroforestry systems does not lead to decreasing net soil carbon stocks of each year in the transition period. However, uncertainties arising from this issue should be addressed in future analyses.

Our analysis was conducted at the farm-level using an existing farm structure that in its size is representative for Swiss suckler cow breeding farms. Stewart et al. (2009) found that heterogeneity in farm structure will lead to different numerical results across farms. Thus, the site-specific, spatially explicit analysis of mitigation options should be addressed in further research. In addition, technical uncertainties arising from specific mitigation options and agroforestry should be empirically addressed in further research. 
Our results show that reductions of greenhouse gas emissions per kilogram of meat are not free of costs. Thus, consumers would have to pay for these reductions. Studies on consumers' willingness to pay for emission reductions, for instance by using alternative electricity and fuel production techniques (Roe et al. 2001; Nomura and Akaib 2004) have shown that there is a positive willingness to pay for such environmental service. Different studies also show that consumers are ready to pay in addition for food with a lower carbon footprint or they at least choose products with a better carbon balance if the products else are identical (Bolwig and Gibbon 2009; Vanclay et al. 2010). Such willingness to pay is expected to be rather high in Switzerland, because the Swiss population has a high demand for environmentally friendly, low emission agriculture (Haller 2011). In addition, we think that the reduction of emissions from meat production, or even an emission-neutral meat production, is a large opportunity for producers because this could be used to label their products and could thus be used for further product differentiation. As shown in Table 5, subsidies in form of general and ecological direct payments as well as the associated cross compliance requirements play an important role in Swiss agricultural production. The reduction of emissions from animal production could thus also be fostered by integrating greenhouse gas emission restrictions in the cross compliance restrictions or by introducing additional ecological direct payments for low- or zero-emission animal production.

\section{Conclusion}

In our assessment of the economic suitability of mitigation and offset strategies to reduce GHG emissions for common suckler farming systems in Switzerland, only the agroforestry system, with its carbon sequestration potential, leads to significant GHG emission reductions at reasonable costs.

Other mitigation options considered in our study do not have the potential to reduce GHG emissions on a large scale. They neither have the potential to reduce a large share of GHG emissions, nor are they inexpensive enough to make implementation possible.

Additional production costs for carbon improved meat will be in a moderate range making it marketable. This is even more the case as the farmers' animal production costs represent only a part of the price the consumer pays for meat in the shop.

Consumers are becoming more and more sensitive to climate change and are modifying their behaviour accordingly when buying meat in the grocery store (Vanclay et al. 2010). For farms to benefit from this consumer trend, the emissions of the whole value chain must be assessed and optimised. For the agricultural link of the value chain, agroforestry is a way to contribute to GHG mitigation and to adapt to this future consumer trend.

\section{References}

Amaudruz M, Morier R, Zimmermann A et al (2003) Wegleitung Suisse-Bilanz. Landwirtschaftliche Beratungszentrale Lindau LBL, Eschikon (Switzerland)

Amon B, Kryvoruchko V, Amon T (2006) Influence of different methods of covering slurry stores on greenhouse gas and ammonia emissions. Int Congr Ser 1293:315-318

Arevalo CBM, Bhatti JS, Changa SX, Sidders D (2011) Land use change effects on ecosystem carbon balance: from agricultural to hybrid poplar plantation. Agr Ecosyst Environ 141:342-349

Arrigo Y, Chaubert C, Daccord R et al (1994) Fütterungsempfehlungen und Nährwerttabellen für Wiederkäuer. Eidgenössische Forschungsanstalt für viehwirtschaftliche Produktion, Posieux (Switzerland) 
Beauchemin KA, Janzen HH, Little SM et al (2010) Life cycle assessment of greenhouse gas emissions from beef production in western Canada: a case study. Agr Syst 103:371-379

Bernesson S (2004) Life Cycle Assessment of Rapeseed Oil, Rape Methyl Ester and Ethanol as Fuels-a Comparison between large- and small-scale Production. Department of Biometry and Engineering, Swedish University of Agricultural Sciences, Uppsala

Boessinger M, Buchmann M, Hanhart J et al (2009) Deckungsbeiträge - Ausgabe 2009. Agridea, Eschikon (Switzerland)

Bolwig S, Gibbon P (2009) Counting Carbon in the Marketplace: Part I-Overview Paper. Paper presented at the Global Forum on Trade and Climate Change, Paris 9 and 10 June 2009

Buysse J, Van Huylenbroeck G, Lauwers L (2007) Normative, positive and econometric mathematical programming as tools for incorporation of multifunctionality in agricultural policy modelling. Agr Ecosyst Environ 120:70-81

Casey JW, Holden NM (2006) Quantification of GHG emissions from sucker-beef production in Ireland. Agr Syst 90:79-98

Cousin C (2009) "Etiquetage carbone": premiers tests. L'Enterprise.com, http://lentreprise.lexpress.fr/ developpement-durable/etiquetage-carbone-premiers-tests_19851.html, Cited 3 Oct 2011

Crosson P, Shalloo L, O'Brien D et al (2011) A review of whole farm systems models of greenhouse gas emissions from beef and dairy cattle production systems. Anim Feed Sci Tech 166-167:29-45

De Wit CT, van Keulen H, Seligman NG, Spharim I (1988) Application of interactive multiple goal programming techniques for analysis and planning of regional agricultural development. Agr Syst 26:211-230

Del Prado A, Chadwick D, Cardenas L et al (2010) Exploring systems responses to mitigation of GHG in UK dairy farms. Agr Ecosyst Environ 136:318-332

Dütschler-Herrmann A, Stoll P, Wiedmer H et al (2006) Pflanzen und Tiere 2006. Wirz Verlag, Basel

Edward-Jones G (2006) Modelling farmer decision-making: concepts, progress and challenges. Anim Sci 82:783-790

Eichhorn MP, Paris P, Herzog F et al (2006) Silvoarable systems in Europe - past, present and future prospects. Agrofor Syst 67:29-50

El Benni N, Lehmann B (2010) Swiss agricultural policy reform: landscape changes in consequence of national agricultural policy and international competition pressure. In: Primdahl J, Swaffield S (eds) Globalisation and agricultural landscapes - change patterns and policy trends in developed countries. Cambridge University Press, Cambridge, pp 73-94

Finger R, Lazzarotto P, Calanca P (2010) Bio-economic assessment of climate change impacts on managed grassland production. Agr Syst 103:666-674

Firestone M, Davidson E (1989) Microbiological basis of NO and N2O production and consumption in soil. In: Andreae MO, Schimel DS (eds) Exchange of trace gases between terrestrial ecosystems and the atmosphere. Wiley, Oxford, pp 7-21

Foley PA, Crosson P, Lovett DK, Boland TM, O'Mara FP, Kenny DA (2011) Whole-farm systems modelling of greenhouse gas emissions from pastoral suckler beef cow production systems. Agr Ecosyst Environ $142: 222-230$

Ford-Robertson J, Robertson K, Maclaren P (1999) Modelling the effect of land-use practices on greenhouse gas emissions and sinks in New Zealand. Environ Sci Policy 2:134-144

Gazzarin C, Albisser Vögeli G (2010) ART-Bericht 733-Maschinenkosten 2010. Forschungsanstalt Agroscope Reckenholz-Tänikon ART, Ettenhausen (Switzerland)

Grainger C, Beauchemin KA (2011) Can enteric methane emissions from ruminants be lowered without lowering their production? Anim Feed Sci Tech 166-167:308-320

Haller T (2011) Bedeutung der Landwirtschaft in einer zunehmend urbanen Gesellschaft. Dissertation, ETH Zürich

Hartmann M, Huber R, Peter S, Lehmann B (2009) Strategies to mitigate greenhouse gas and nitrogen emissions in Swiss agriculture: the application of an integrated sector model. IED Working Paper 9, ETH Zurich, Institute for Environmental Decisions, Zürich (Switzerland)

Houghton JT, Maira Filho LG, Lim B et al (eds) (1997) Revised 1996 IPCC Guidelines for National Greenhouse Gas Inventories. IPCC/OECD/IEA. UK Meteorological Office, Bracknell (UK)

IPCC (2000) Good practice guidance and uncertainty management in national greenhouse gas inventories. Intergovernmental Panel on Climate Change (IPCC), Institute for Global Environmental Strategies, Tokyo (Japan)

IPCC (2007) Climate Change 2007: Synthesis report. Contribution of working groups I, II and III to the Fourth Assessment Report of the Intergovernmental Panel on Climate Change. IPCC, Geneva (Switzerland)

Janssen S, van Ittersum MK (2007) Assessing farm innovations and responses to policies: a review of bioeconomic farm models. Agr Syst 94:622-636 
Johnson KA, Johnson DE (1995) Methane emissions from cattle. Anim Sci 73:2483-2492

Jose S (2009) Agroforestry for ecosystem services and environmental benefits: an overview. Agrofor Syst $76: 1-10$

Karrer S, Tikir A (2010) Swiss Farmers' Perception of and Response to Climate Change_Climate Change Perceptions and Willingness to Support Policy Measures. Paper presented at the XIV Conference on Foundations and Applications of Utility, Risk and Decision Theory (FUR), Newcastle University, Newcastle (UK), 15-18 June, 2010

Kern R (2006) Bedeutung und Wirtschaftlichkeit des Streuobstbaus in Österreich. Diploma thesis at the Universität für Bodenkultur. Universität für Bodenkultur Wien, Institut für Agrar und Forstökonomie, Wien (Austria)

Landi Jungfrau (2008) Verkaufspreise ab Landi-Lager-2. Stufe 2008. http://www.landijungfrau.ch/ files/pl-duenger-2008 —-stufe-2—ab-lager.pdf. Cited 16 June 2011

Martin C, Morgavi DP, Doreau M (2010) Methane mitigation in ruminants: from microbe to the farm scale. Animal 4:351-365

McNeill A, Unkovich M (2007) The nitrogen cycle in terrestrial ecosystems. In: Marschner P, Rengel Z (eds) Nutrient cycling in terrestrial ecosystems. Springer, Berlin

Merino P, Menendez S, Pinto M et al (2005) 3,4-Dimethylpyrazole phosphate reduces nitrous oxide emissions from grassland after slurry application. Soil Use Manag 21:53-57

Meyer-Aurich A (2005) Economic and environmental analysis of sustainable farming practices — a Bavarian case study. Agr Syst 86:190-206

Minonzio G, Grub A, Fuhrer J (1998) Methan-Emissionen der schweizerischen Landwirtschaft. Schriftenreihe Umwelt Nr. 298. Bundesamt für Umwelt, Wald und Landschaft (BUWAL), Bern (Switzerland)

Möhring A, Zimmermann A, Mack G, Mann S, Ferjani A, Gennaio MP (2010) Modelling structural change in the agricultural sector-An agent-based approach using FADN data from individual farms. Paper presented at the 114th EAAE Seminar, Berlin, 15-16 April, 2010

Mutterkuh Schweiz (2011) Fleischrinderrassen. http://www.mutterkuh.ch/de/herdebuch/rassen/. Cited 20 June 2011

Nelson T, Wood E, Hunt J, Thurbon C (2011) Improving Australian greenhouse gas reporting and financial analysis of carbon risk associated with investments. Sustainability Accounting, Management and Policy Journal 2:147-157

Nomura N, Akaib M (2004) Willingness to pay for green electricity in Japan as estimated through contingent valuation method. Appl Energ 78:453-463

Palma JHN, Graves AR, Bunce RGH et al (2007) Modeling environmental benefits of silvoarable agroforestry in Europe. Agr Ecosyst Environ 119:320-334

Peter S (2008) Modellierung agrarökologischer Fragestellungen unter Berücksichtigung struktureller Veränderungen in der Schweizer Landwirtschaft. Dissertation, ETH Zürich

Reidy B, Menzi H (2005) Ammoniakemissionen in der Schweiz: Neues Emissionsinventar 1990 und 2000 mit Hochrechnungen bis 2003. Technischer Schlussbericht zuhanden BUWAL. Schweizerische Hochschule für Landwirtschaft (SHL), Zollikofen (Switzerland)

Roe B, Teisl MF, Levy A, Russell M (2001) US consumers' willingness to pay for green electricity. Energ Policy 29:917-925

Rypdal K, Winiwarter W (2001) Uncertainties in greenhouse gas emission inventories-evaluation, comparability and implications. Environ Sci Policy 4:107-116

SAFE (2005) Silvoarable Agroforestry for Europe (SAFE).Synthesis of the SAFE project (August 2001January 2005) (SAFE final report). wwwl.montpellier.inra.fr/safe/index.php. Cited 27 Jan 2011

Schils RLM, Verhagen A, Aarts HFM, Sebek LBJ (2005) A farm level approach to define successful mitigation strategies for $\mathrm{GHG}$ emissions from ruminant livestock systems. Nutr Cycl Agroecosys $71: 163-175$

Schmid M, Neftel A, Fuhrer J (2000) Lachgasemissionen aus der Schweizer Landwirtschaft. Schriftenreihe der FAL 33. Eidgenössische Forschungsanstalt für Agrarökologie und Landbau, FAL Reckenholz, Zürich (Switzerland)

Schmid M, Neftel A, Riedo M, Fuhrer J (2001) Process-based modelling of nitrous oxide emissions from different nitrogen sources in mown grassland. Nutr Cycl Agroecosys 60:177-187

Schoch H (2009) Preiskatalog. Agridea, Eschikon (Switzerland)

Stewart AA, Little SM, Ominski KH et al (2009) Evaluating greenhouse gas mitigation practices in livestock systems: an illustration of a whole-farm approach. J Agr Sci 147:367-382

SwissOlio (2007) Stellungnahme der Speiseöl-, Speisefett- und Margarine-Industrie. http://www.kmu.unisg.ch/org/ kmu/web.nsf/SysWebRessources/Studie+Argrarfreihandelsabkommen+EUSchweiz,+SCFA,+Stellungsnahme + Swiss+Olio/\%24FILE/Stellungnahme+SwissOlio+zur+Studie+Uni+St.+Gallen+-+22.1.07+def.pdf, Cited 16 June 2011 
UNFCCC (2008) Challenges and opportunities for mitigation in the agricultural sector. Technical paper (FCCC/TP/2008/8). United Nations Framework Convention on Climate Change (UNFCCC), Geneva (Switzerland)

Van der Werf HMG, Petit J, Sanders J (2005) The environmental impacts of the production of concentrated feed: the case of pig feed in Bretagne. Agr Syst 83:153-177

Vanclay JK, Shortiss J, Aulsebrook S et al (2010) Customer response to carbon labelling of groceries. J Consum Policy. doi:10.1007/s10603-010-9140-7

Vergé XPC, Dyer JA, Desjardins RL, Worth D (2007) Greenhouse gas emissions from the Canadian dairy industry in 2001. Agr Syst 94:683-693

Veysset P, Lherm M, Bébin D (2010) Energy consumption, greenhouse gas emissions and economic performance assessments in French Charolais suckler cattle farms: Model-based analysis and forecasts. Agr Syst 103:41-50

Weiske A, Benckiser G, Ottow JCG (2001) Influence of the nitrification inhibitor 3,4-dimethylpyrazole phosphate (DMPP) in comparison to dicyandiamide (DCD) on nitrous oxide emissions, carbon dioxide fluxes and methane oxidation during 3 years of repeated application in field experiments. Biol Fert Soils 34:109-117

Williams AG, Audsley E, Sandars DL (2006) Determining the environmental burdens and resource use in the production of agricultural and horticultural commodities. Main Report. Defra Research Project IS0205. Cranfield University and Defra, Bedford (UK)

Wright AG, Klieve AV (2011) Does the complexity of the rumen microbial ecology preclude methane mitigation? Anim Feed Sci Tech 166-167:248-253

Zander P, Groot JCJ, Josien E, Karpinski I, Knierim A, Meyer BC, Madureira L, Rambonilaza M, Rossing WAH (2008) Farm models and economic valuation in the context of multifunctionality: a review of approaches from France, Germany, The Netherlands and Portugal. Int J Agri Resour 7:339-360

Zeeman MJ, Hiller R, Gilgen AK, Michna P, Pluss P, Buchmann N, Eugster W (2010) Management and climate impacts on net $\mathrm{CO} 2$ fluxes and carbon budgets of three grasslands along an elevational gradient in Switzerland. Agr Forest Meteorol 150:519-530

Zerulla W, Barth T, Dressel J et al (2001) 3,4-Dimethylpyrazole phosphate (DMPP) - a new nitrification inhibitor for agriculture and horticulture. Biol Fert Soils 34:79-84 